\title{
The Relationship between Congenital Zika and Bruxism in Early Childhood
}

\author{
José Artur Oliveira Pereira', Mariana Dantas Do Nascimento', Edilson Martins Rodrigues Neto1,", Fernanda Maria Teófilo Campos², \\ Francisco César Monteiro Chaves Filho', Fernanda Dantas Sales Pimentel ${ }^{3}$, Cristiane Sá Roriz Fonteles ${ }^{1}$, Patricia Leal Dantas Lobo ${ }^{1}$ \\ 'Faculty of Pharmacy, Dentistry and Nursing College - Federal University of Ceara, Fortaleza, CE, BRAZIL. \\ 2Department of Physiology and Pharmacology - Federal University of Ceara, Fortaleza, CE, BRAZIL. \\ ${ }^{3}$ Health Sciences Center - State University of Ceará, Fortaleza, CE, BRAZIL.
}

\begin{abstract}
Zikavirus infection during pregnancy generates a series of neurological, musculoskeletal and sensory disorders known as Congenital Zika Virus Syndrome (CZVS), being responsible for even oral changes. This study aims to review the literature to address the relationship between congenital Zika and the development of bruxism in childhood. To achieve this goal, a research was carried out by means of Biblioteca Virtual em Saúde (BVS), PubMed and Google Scholar databases, using the keywords "Zika Virus Infection", "Bruxism" and "Dentistry". After a critical reading of papers and abstracts, a total of 15 articles considered relevant to the theme were selected and they were published in the last 5 years. Bruxism reaches a prominent level in several studies, with its prevalence varying between $20.3 \%$ and $100 \%$ in the clinical articles analyzed. Claiming it is a recent condition studied, there are still few studies evaluating this incidence in pediatric patients with CZVS, but there are already strong indications of this relationship, and it is extremely important to assess these factors and approach the case in partnership with a multidisciplinary team when necessary. In conclusion,
\end{abstract}

there is evidence of a relationship between bruxism and SCZV , and the integration of different health professionals in the monitoring of these syndromic children is essential to better diagnose and intervene in the associated conditions, including treating this parafunctional oral habit more effectively and the impacts of this condition on the quality of life of the patient and the caregiver.

Key words: Zikavirus Infection, Bruxism and Dentistry, Childhod, Congenital infection.

\section{Correspondence}

Dr. Edilson Martins Rodrigues Neto,

Department of Pharmacy, Dentistry and Nursing College, Federal University of Ceara, Fortaleza, CE, BRAZIL.

Email id: edilsonmrneto@hotmail.com

DOI: 10.5530/jyp.2022.14.6

\section{INTRODUCTION}

Congenital Zikavirus Syndrome (SCZV) is a chronic disorder characterized by neurological, musculoskeletal and sensory problems, caused by vertical Zika virus infection. ${ }^{1}$ There are no vaccines, drugs or immunobiological agents capable of preventing the transmission of this arbovirus. ${ }^{2}$ The condition has gained considerable repercussion in Brazil, especially in the Northeast region, as it has been responsible for an increasement in the number of cases of microcephaly in newborns. ${ }^{3}$

With about 3500 confirmed cases from November 2015 till October 2019, this disabling physical condition requires multidisciplinary care in both primary and specialized care. ${ }^{4}$ There are, however, many gaps in the understanding of SCZV, including its relationship with affected individual oral health. ${ }^{5}$

It is known that children with SCZV may be at greater risk of dental problems, creating significant morbidity that can also affect wellbeing and quality of life, such as periodontal diseases, tooth decay, malocclusion, micrognathia, delayed tooth eruption, dysphagia, dental trauma, palate alterations, airway obstruction, speech problems and bruxism. ${ }^{5,6}$ In addition, these individuals may encounter barriers in accessing oral health care. ${ }^{1}$

Bruxism reaches a prominent level among the alterations mentioned that affect individuals with SCZV, as it is a multifactorial disease in which different psychological and emotional aspects, such as stress and anxiety, interact, and there may also be the participation of systemic and local factors, for example sleeping disorders and tonsil hyperplasia.?
Some factors are already mentioned as probable explanations for the relationship between bruxism and this syndrome, for example, the Zikavirus tropism for nervous tissue, the dental lamina formation from neural crest cells and, finally, the serious repercussions that infections in early pregnancy can cause, including for oral health. Thus, it is essential that dentists know how to recognize this possible oral manifestation and its causal factors, in order to properly proceed with the dental treatment and rehabilitation of these children. ${ }^{8}$

Thus, this study focused on the following guiding question: Is there evidence of a relationship between childhood bruxism and children affected by the Congenital Zika Virus Syndrome? From this questioning, the importance of this research is to improve scientific knowledge on this topic, in addition to helping to design strategies for prevention, health promotion and recovery for this population.

\section{METHODOLOGY}

This study is a literature review, whose searches for scientific studies were performed in the Virtual Health Library (VHL), PubMed and Google Scholar databases, using the descriptors "Congenital Zika Syndrome", "Bruxism" and "Dentistry", also using the Portuguese versions of these terms. The filters used corresponded to the period of publication in the last five years and complete works published in Portuguese or English. In all, 15 articles considered relevant to the theme were selected, after a critical reading of the titles and abstracts obtained by the bibliographic survey. 


\section{LITERATURE REVIEW}

According to the review by Leite and Varellis, in 2016, the latest studies showed that approximately 1650 children with microcephaly in Brazil had some type of oral alteration, such as periodontal diseases, tooth decay, malocclusion, micrognathia, delay in tooth eruption, dysphagia, bruxism and dental trauma. ${ }^{6}$

In a case reported by Delgado, Cavalcanti and Mendes (2017), it was possible to follow-up a baby with microcephaly whose mother, through clinical examination, was diagnosed with Zika virus in the $3^{\text {rd }}$ month of pregnancy, with fever and reddish spots on the body. During this followup, the patient's guardian informed that during the primary molars eruption, the child performed dental clenching and grinding while sleeping. ${ }^{9}$

Some clinical studies, researches or series of case reports which will be discussed below, brought in their results percentages regarding the prevalence of bruxism in the population with Zika virus analyzed, obtaining very expressive numbers that can be observed in a summarized way in Table 1.

The comparative study by Siqueira, Santos and Cabral (2018), for example, analyzed a sample of 108 children, where 54 of this total had microcephaly related to congenital Zikavirus infection and the other half had no diseases of any kind, with both groups matched for age, sex and family income proportionally. A considerable incidence of bruxism (20.3\% - 11 cases) was found in the group of children with microcephaly compared to the group of healthy children. ${ }^{10}$

In the study by Amorim et al. (2018), in turn, the participants were divided into two groups, comprising one of 8 children with microcephaly caused by ZIKV (G1) and the other consisting of 24 children without this syndrome (G2). It was seen that $50 \%$ of G1 received a positive diagnosis for bruxism, while no participant in G2 obtained such clinical statement. ${ }^{11}$

The observational, descriptive and cross-sectional work by Cota et al. (2020) reported a series of cases involving 12 patients aged from 36 to 40 months and found as results that, in relation to deleterious oral habits, bruxism was the most frequent oral occurrence found in patients, being present in $58.3 \%$ of the clinical conditions evaluated. ${ }^{12}$

More recently, the case report study by Aragón, Díaz and Contreras (2021) aimed to describe dental, occlusal and craniofacial characteristics based on the case report of 3 children affected by congenital Zika infection. It was noticed that all of them had bruxism and that this

Table 1: Relative prevalence of bruxism analysis in all children with Congenital Zika Virus Syndrome observed in clinical studies.

\begin{tabular}{cccc}
\hline Author & Research city & $\begin{array}{c}\text { Children with } \\
\operatorname{SCZV~}(\mathbf{n})\end{array}$ & $\begin{array}{c}\text { Bruxism } \\
\text { Prevalence } \\
(\%)\end{array}$ \\
\hline $\begin{array}{c}\text { Squeira, Santos } \\
\text { and Cabral } \\
2018\end{array}$ & $\begin{array}{c}\text { Paraiba } \\
\text { (Brasil) }\end{array}$ & 54 & 20.3 \\
$\begin{array}{c}\text { Amorin } \text { et al., } \\
2018\end{array}$ & $\begin{array}{c}\text { Rio Grand do Norte } \\
\text { (Brasil) }\end{array}$ & 08 & 50 \\
$\begin{array}{c}\text { Cota } \text { et al., } \\
2020\end{array}$ & $\begin{array}{c}\text { Maceio } \\
\text { (Brasil) }\end{array}$ & 12 & \\
$\begin{array}{c}\text { Aragon, Diaz e } \\
\text { Contreras } \\
\text { 2021 }\end{array}$ & $\begin{array}{c}\text { Valle del Cauca } \\
\text { (Colombia) }\end{array}$ & 03 & \\
\hline
\end{tabular}

parafunctional habit was commonly present in both wakefulness and sleep..$^{13}$

\section{DISCUSSION}

It is noted that, although most scientific studies focus on other oral comorbidities, for example, delays in tooth eruption ${ }^{5}$ or enamel changes, ${ }^{10}$ these studies also approached that pediatric patients with SCZV could be at a high risk for the signs and symptoms manifestation related to bruxism. It is worth mentioning that these publications explained this relationship by supporting that the neurological disorders presented in these syndromic individuals would predispose to parafunctional behaviors installation, such as grinding or clenching teeth.

The literature, however, presents conflicting data on the prevalence of this oral condition in Zika syndromic individuals, because the results depend on methodological standardization both for the diagnosis and for the correct comparative analysis between the data obtained in epidemiological research. ${ }^{7}$

It is worth highlighting that Zika virus has tropism for cells that make up the nervous tissue and there is already a consensus in the scientific literature that SCZV has a strong association with changes in muscle tone and joint contractures in the affected patient. ${ }^{10,14}$ It still have to be defined if these factors are enough to characterize a real picture of bruxism.

Bearing in mind that SCZV is a recent condition, studies that analyze structural and behavioral changes in the maxillofacial complex are still incipient and there are no guidelines for the care of children with this syndrome. The dentist, however, as part of a multidisciplinary and specialized team, needs to be aware of new scientific publications and prepared for the care, treatment and monitoring of these individuals in public and private health systems. ${ }^{1}$

Due to this wide spectrum of clinical changes involving Zika virus infection sequelae in children neurodevelopment, the assessment of the psychological risk of factors for bruxism, such as stress and anxiety, depends mainly on professional experience. At first, it is mandatory that the dentist collects as much information as possible from caregivers through anamnesis. Another important strategy involves focusing on neurological disorders detection that could be responsible for abnormal oral movements during sleep, it being essential to communicate with the neurologist to assess the case. ${ }^{8}$

Regarding the bruxism prevalence among population with SCZV, the study by Siqueira, Santos and Cabral (2018) found that, happening in $20.3 \%$ of the individuals analyzed, the presence of this condition was a considerable oral characteristic in the sample. The authors even mentioned that parafunctional habits are characteristics constantly present in people with special needs, being neurological disorders an important risk factor for the development of such dysfunction. ${ }^{10}$

The article by Amorim et al. (2018), in addition to finding a significant percentage of bruxism prevalence in children with Zika virus (50\%), made a warning when mentioning that this relationship between oral condition and systemic disease has impacts beyond the individual's health, but also causing negative repercussions on family social relationships, on the quality of professional management when it is not qualified, and on the economy of the public health system. ${ }^{11}$

The studies by Cota et al. (2020) and Aragón, Díaz and Contreras (2021) were the ones that showed the highest rate of bruxism for the population analyzed, $58.3 \%$ and $100 \%$, respectively. This first work mentions that discrepancies in the prevalence of this oral condition are common both in groups with SCZV and in healthy children, and therefore there should be a methodological standardization so that the results are reliable with reality and can be more easily compared with each other. ${ }^{12,13}$ 
The research by Aragón, Díaz and Contreras (2021), in turn, raises the hypothesis that continuous bruxism possibly compensates the dental arches' transverse development, since all children evaluated during the research were fed with a liquid or pasty diet and, therefore, they did not have enough masticatory stimulation. On the other hand, these authors state that such a habit is a parafunction with harmful consequences, as it triggers wear on the dental surfaces, muscle fatigue and temporomandibular disorders over time. ${ }^{13}$

Furthermore, through the analysis of the presented works, it is marked a greater focus of clinical research in the Brazil's Northeast region can be observed, and this occurrence is easily justified, since this is the area where the majority of cases of microcephaly associated with congenital infection are concentrated by Zika virus in recent years. ${ }^{1,3,8,15,16}$ There is also a slight increasing trend of publications discussing the subject over time, as most of the studies approached took place more recently.

Finally, knowing the dysfunctions associated with SCZV and the main oral problems of pediatric patients, such as bruxism, help in care directioning with the appropriated treatment, in order to obtain better clinical management during dental follow-up. Knowledge of these conditions and the existing intrinsic relationship, then, provides benefits for the quality of life of these individuals. ${ }^{15,16}$

\section{FINAL CONSIDERATION}

Given the above, it is possible to suggest a relationship between Congenital Zika Virus Syndrome and bruxism, that the dentist should be aware of the clinical oral findings of patients with this condition in order to better address these cases of parafunctional disorders.

Early diagnosis of bruxism through regular consultations is essential and, in addition, it is fundamental to guide caregivers of these children about this frequent oral problem and the importance of dental followup. The dentist integration in a multidisciplinary team to monitor this population is of paramount importance, as the interventions carried out should promote the patient's oral and systemic health.

Therefore, it will be easier to develop targeted dental treatments, providing a better quality of life for patients and the family that accompany them. Finally, it is recommended that further studies on this relationship be carried out.

\section{CONFLICT OF INTEREST}

The authors declare that there is no conflict of interest.

\section{REFERENCES}

1. Siqueira RMPd, Marinho ABAdS, Santos MTBRd, Cabral GMP. Dental care for children with Congenital Zika Syndrome. RGO Rev Gaúch. Odontol. 2020;68. doi: 10.1590/1981-863720200001420180012.

2. Feitosa IML, Schuler-Faccini L, Sanseverino MTV. Aspectos importantes da Síndrome da Zika Congênita para o pediatra e o neonatologista. Bol Cient Pediatr. 2016;5(3)

3. De Menezes PCB, Ponte YdO, Girão DC, Vasconcelos AdA, Martins LdA, Cunha KAC, et al. Síndrome congênita do Zika vírus - um novo desafio ao odontopediatra: uma revisão bibliográfica. Rev Eletrônica Acervo Saúde. 2020;12(3):2544-e2544, doi: 10.25248/reas.e2544.2020.

4. Epidemiológico B. Brazil. Ministério da Saúde. Secretaria de Vigilância em Saúde. Síndrome congênita associada à infecção pelo vírus Zika: Situação epidemiológica, ações desenvolvidas e desafios, 2015 a 2019. 2019;50:1-31.

5. Marinho JVM, Mousinho KC, Panjwani CMBRG, Ferreira SMS, Vanderlei AD. Aspectos clínicos da cavidade oral de pacientes com a síndrome congênita do Zika: Revisão da literatura. Div Journ. 2020;5(1):57-65. doi: 10.17648/diversitasjournal-v5i1-932

6. Leite CN, Varellis MLZ. Microcefalia e a odontologia brasileira. J Health NPEPS. 2016:297-304

7. Rédua RB, Kloss PCA, Fernandes GB, Da Silva PLF. Bruxismo na infância aspectos contemporâneos no século 21 - revisão sistemática. Full Dent Sci. 2019;10(38):131-7. doi: 10.24077/2019;1038-131137.

8. Cota ALS, Lopes MGM, Pio IM, Oliveira MJd, Rodrigues DF, Panjwan CMBRG. Oral findings in children with congenital Zika Syndrome: A case series SaudPesq. 2020;13(1):133-42. doi: 10.17765/2176-9206.2020v13n1p133-142.

9. Delgado GKG, Cavalcanti MEA, Mendes PA. Abordagem Odontológica a um Bebê Portador De Microcefalia: Relato de Caso. Rev Acad Bras Odontol. 2017;6(2):92-8.

10. Siqueira RMP, Santos MTBR, Cabral GMP. Alterations in the primary teeth of children with microcephaly in Northeast Brazil: A comparative study. Int $J$ Paediatr Dent. 2018;28(5):523-32. doi: 10.1111/ipd.12402.

11. Amorim JGP. Condição de saúde oral em crianças com microcefalia por infecção pelo Zika vírus: Estudo transversal observacional [Master's thesis]. Natal, BRAZIL: Universidade Federal do Rio Grande do Norte; 2018.

12. Cota ALS, et al. Assistência odontológica na atenção primária: Atendimento integral a bebês com a Síndrome Congênita do Zika. Temas Saúde. 2019;19(4).

13. Aragón N, Díaz C, Contreras A. Dental, Occlusal, and craniofacial features of children with microcephaly due to congenital Zika infection: 3 cases report from Valle del Cauca, Cali-Colombia-2020. Cleft Palate Craniofac J. 2021;58(10):1318-25. doi: 10.1177/1055665621990978.

14. Costello A, DuaT, Duran P, Gülmezoglu M, Oladapo OT, Perea W, et al. Defining the syndrome associated with congenital Zika virus infection. Bull World Health Organ. 2016;94(6):406-406A. doi: 10.2471/BLT.16.176990.

15. Gusmão TPL. Prevalência das alterações orais e craniofaciais em crianças portadoras da síndrome congênita do Zika vírus [Master's thesis]. Recife, BRAZIL: Universidade Federal de Pernambuco; 2017.

16. Souza VAF, Abreu MHNG, Resende VLS, Castilho LS. Factors associated with bruxism in children with developmental disabilities. Braz Oral Res. 2015;29(1):01-5. doi: 10.1590/1807-3107BOR-2015.vol29.0009

Article History: Received: 29-10-2021; Revised: 03-12-2021; Accepted: 01-01-2022

Cite this article: Pereira JAO, Nascimento MDD, Neto EMR, Campos FMT, Filho FCMC, Pimentel FDS, Fonteles CSR, Lobo PLD. The Relationship between Congenital Zika and Bruxism in Early Childhood. J Young Pharm. 2022;14(1):30-2. 